\title{
Immobilization of Fluorine in Aqueous Solution by Calcium Aluminum Ferrite and the Mixture of Calcium Aluminate and Gypsum
}

\author{
Hongye HE and Hideaki SUITO \\ Institute of Multidisciplinary Research for Advanced Materials, Tohoku University, Katahira, Aoba-ku, Sendai 980-8577, Japan.
}

(Received on November 26, 2001; accepted in final form on March 18, 2002)

\begin{abstract}
The immobilization of fluorine by calcium aluminum ferrites has been studied using 20 mass ppm F-containing aqueous solution. It is found that the rate of the $\mathrm{F}$ immobilization by $\mathrm{Ca}_{2}(\mathrm{Al}, \mathrm{Fe})_{2} \mathrm{O}_{5}$ is initially slower than that by $3 \mathrm{CaO} \cdot \mathrm{Al}_{2} \mathrm{O}_{3}$ at the solid/liquid ratio of $1 / 200$, but a similiar immobilization degree is obtained at later stage. The hydration product contributed to the $\mathrm{F}$ immobilization is the $\mathrm{Ca}_{3}(\mathrm{Al}, \mathrm{Fe})_{2}(\mathrm{OH}, \mathrm{F})_{12}$ phase, which is confirmed by the combination of XRD and electron microprobe analysis. For a ferrite phase of $\mathrm{Ca}_{2}\left(\mathrm{Al}_{0.68} \mathrm{Fe}_{0.32}\right)_{2} \mathrm{O}_{5}$, the hydration product has a chemical composition of $\mathrm{Ca}_{3} \mathrm{Al}_{1.54} \mathrm{Fe}_{0.46}\left[(\mathrm{OH})_{1-x} \mathrm{~F}_{x}\right]_{12}(x=0$ 0.13). The $\mathrm{F}$ immobilization by $2 \mathrm{CaO} \cdot \mathrm{Fe}_{2} \mathrm{O}_{3}$ does not occur to a significant extent, but the $\mathrm{F}$ immobilization by $12 \mathrm{CaO} \cdot 7 \mathrm{Al}_{2} \mathrm{O}_{3}$ is accelerated with the addition of $2 \mathrm{CaO} \cdot \mathrm{Fe}_{2} \mathrm{O}_{3}$ due to the formation of the $\mathrm{Ca}_{3}(\mathrm{Al}, \mathrm{Fe})_{2}(\mathrm{OH}, \mathrm{F})_{12}$ phase. It is also observed that $\mathrm{F}$ can be immobilized by the formation of ettringite $\left(3 \mathrm{CaO} \cdot \mathrm{Al}_{2} \mathrm{O}_{3} \cdot 3 \mathrm{CaSO}_{4} \cdot 32 \mathrm{H}_{2} \mathrm{O}, 3 \mathrm{CaO} \cdot \mathrm{Fe}_{2} \mathrm{O}_{3} \cdot 3 \mathrm{CaSO}_{4} \cdot 32 \mathrm{H}_{2} \mathrm{O}\right)$ through the substitution of $\mathrm{F}$ ion for the $\mathrm{SO}_{4}^{2-}$ site.
\end{abstract}

KEY WORDS: immobilization; fluorine; calcium aluminum ferrite; ettringite.

\section{Introduction}

Fluorine has become a health and environmental concern ever since the discovery that fluoride is the cause of mottled enamel (dental fluorosis) and skeletal fluorosis. Human exposure to fluorides was primarily caused by the natural sources such as naturally fluoridated drinking water and fluoride uptake in fruits and vegetables from the soil and seafood. In recent years, however, F-containing waste has become a major concern on the $\mathrm{F}$ contamination.

The major waste form generated from ironmaking and steelmaking industry is slags with complicated compositions and these slags usually carry hazardous elements which sabotage the recycle and disposal of slags. Fluorine is one of the most commonly concerned hazardous elements in the steelmaking slags due to the usage of $\mathrm{CaF}_{2}$ in refining process, particularly for the production of high quality steels. Fluorine contamination to the groudwater can occur when steelmaking slags are reused as road construction materials or subjected to landfill. The natural processes such as the weathering and leaching by rainfall can bring more fluorine into the groudwater. Therefore, a research has been carried out to immobilize fluorine in hot metal dephosphorization slags by using secondary refining slags whose main components are $\mathrm{CaO}, \mathrm{Al}_{2} \mathrm{O}_{3}$, and $\mathrm{SiO}_{2}$. A satisfactory immobilization degree has been attained, indicating that this remediation strategy is effective. However, the immobilization mechanisms involved are not clear yet due to the complexity of the composition of these slags.
The mechanisms of the $\mathrm{F}$ immobilization by calcium aluminates $\left(3 \mathrm{CaO} \cdot \mathrm{Al}_{2} \mathrm{O}_{3}, 12 \mathrm{CaO} \cdot 7 \mathrm{Al}_{2} \mathrm{O}_{3}, 12 \mathrm{CaO} \cdot 7(\mathrm{Al}, \mathrm{Fe})_{2} \mathrm{O}_{3}\right)$ and/or calcium silicates $\left(3 \mathrm{CaO} \cdot \mathrm{SiO}_{2}, 2 \mathrm{CaO} \cdot \mathrm{SiO}_{2}\right)$ which are major mineral phases in these slags have been investigated in the previous study. ${ }^{1,2)}$ It was found that the immobilization of $\mathrm{F}$ ion could be established by the formation of $\mathrm{Ca}_{3} \mathrm{Al}_{2}(\mathrm{OH}, \mathrm{F})_{12}, 3 \mathrm{CaO} \cdot \mathrm{Al}_{2} \mathrm{O}_{3} \cdot \mathrm{Ca}(\mathrm{OH}, \mathrm{F})_{2} \cdot 18 \mathrm{H}_{2} \mathrm{O}$, and $\mathrm{CaO}-\mathrm{SiO}_{2}-\mathrm{H}_{2} \mathrm{O}-\mathrm{F}$ gel. As an outgrowth of the previous investigation, the attention is given to the $\mathrm{F}$ immobilization by using ferrite and etrringite phases.

The immobilization of $\mathrm{F}$ dissolved from hot metal dephosphorization slag in aqueous solution by ferrites has been investigated and the effect of dicalcium ferrite on the F immobilization by calcium aluminates has also been examined. This is of practical importance because calcum aluminates and ferrites usually coexist in cementatious materials. A variety of occurrences of ettringite analogues either in nature or experimental preparation, have made it well known as a host for many elements and give it specific significance in immobilizing waste ions. Therefore, the $\mathrm{F}$ immobilization by the formation of ettringite has also been studied, which has not been payed much attention to so far.

\section{Experimental}

\subsection{Materials}

Dicalcium ferrite $\left(\mathrm{C}_{2} \overline{\mathrm{F}}\right)$ was prepared by heating a mixture of analytical grade $\mathrm{CaCO}_{3}$ and $\mathrm{Fe}_{2} \mathrm{O}_{3}$ at $1100^{\circ} \mathrm{C}$ for 4 days. Ferrites with the compositions of $\mathrm{Ca}_{2}\left(\mathrm{Al}_{0.68} \mathrm{Fe}_{0.32}\right)_{2} \mathrm{O}_{5}$ 
and $\mathrm{C}_{4} \mathrm{~A} \overline{\mathrm{F}}\left(\mathrm{Ca}_{2}\left(\mathrm{Al}_{0.5} \mathrm{Fe}_{0.5}\right)_{2} \mathrm{O}_{5}\right)\left(\mathrm{C}=\mathrm{CaO}, \mathrm{A}=\mathrm{Al}_{2} \mathrm{O}_{3}\right.$ and $\overline{\mathrm{F}}=$ $\mathrm{Fe}_{2} \mathrm{O}_{3}$, hereinafter) were synthesized by sintering mixtures of analytical grade $\mathrm{CaCO}_{3}, \mathrm{Al}_{2} \mathrm{O}_{3}$ and $\mathrm{Fe}_{2} \mathrm{O}_{3}$ in an appropriate proportion at $1300^{\circ} \mathrm{C}$ for one week. The samples were ground to fine powder less than $100 \mu \mathrm{m}$ in diameter. X-ray diffraction (XRD) analysis was used to confirm these compounds. Solid solution of $\mathrm{C}_{3} \mathrm{~A}-5 \mathrm{mass} \% \mathrm{Fe}_{2} \mathrm{O}_{3}$ was prepared by heating a mixture of $\mathrm{C}_{3} \mathrm{~A}$ and analytical grade $\mathrm{Fe}_{2} \mathrm{O}_{3}$ at $1300^{\circ} \mathrm{C}$ for 2 weeks. The method for the preparation of $\mathrm{C}_{3} \mathrm{~A}$ has been already described elsewhere. ${ }^{1)}$ The XRD analysis revealed that the $\mathrm{C}_{3} \mathrm{~A}-5$ mass $\% \mathrm{Fe}_{2} \mathrm{O}_{3}$ solid solution was formed and its X-ray diffraction pattern was almost the same as that of pure $\mathrm{C}_{3} \mathrm{~A}$.

The ettringite phase with fluorine was synthesized by precipitation in 20 mass ppm F-containing aqueous solution in which $\mathrm{C}_{3} \mathrm{~A}$ and $\mathrm{CaSO}_{4} \cdot 2 \mathrm{H}_{2} \mathrm{O}$ particles with the size less than $100 \mu \mathrm{m}$ were added.

\subsection{Shaking Test}

Shaking test was made at room temperature. The test procedure which is basically followed by the Japanese standard test procedure (codified as Environment Agency Notice 46) has been already explained in previous article. ${ }^{1)}$ The solid reactants were added in 20 mass ppm F-containing aqueous solution in $500 \mathrm{ml}$ polyethylene bottle, and then the bottle was shaken horizontally at a speed of 200 times per minute. The solid/liquid ratio was $1 / 100$ and $1 / 200$, and the shaking time was up to $24 \mathrm{~h}$. The F-containing aqueous solution was prepared by diluting hydrofluoric acid $(47 \%)$ with distilled water. The solid phase was separated from the aqueous solution by filtration using the membrane filter with an open pore size of $0.1 \mu \mathrm{m}$ after a certain period of shaking time. The solid phase was subjected to XRD analysis or microscopic observation. The concentration of $\mathrm{F}$ in an aqueous solution was determined by the selective ion-electrode method (JIS-K-0101), and those of $\mathrm{Ca}, \mathrm{Al}$ and $\mathrm{Fe}$ were determined by inductively coupled plasma (ICP) atomic emission spectrometry.

\subsection{Microscopic Observation}

Microscopic observation was carried out by SEM equipped with electron microprobe analysis (energy dispersive or wave-length dispersive spectroscopy) to determine the contents of elements in F-containing minerals. The filtered residue after the shaking test and that in the experiments where large solid particles $(0.84-1.0 \mathrm{~mm})$ were reacted with 20 mass ppm F-containing aqueous solution were used for microscopic observation. These particles were rinsed by methanol, and then dried at $40^{\circ} \mathrm{C}$ for $24 \mathrm{~h}$ in $\mathrm{CO}_{2}$ free environment.

\section{Results and Discussion}

\subsection{Immobilization of $\mathbf{F}$ by Ferrite}

The results for the $\mathrm{F}$ immobilization by $\mathrm{C}_{2} \overline{\mathrm{F}}$, $\mathrm{Ca}_{2}(\mathrm{Al}, \mathrm{Fe})_{2} \mathrm{O}_{5}\left(\mathrm{Ca}_{2} \mathrm{Al}_{1.36} \mathrm{Fe}_{0.64} \mathrm{O}_{5}\right.$ and $\left.\mathrm{C}_{4} \mathrm{~A} \overline{\mathrm{F}}\right)$ and $\mathrm{C}_{3} \mathrm{~A}-$ $5 \% \mathrm{Fe}_{2} \mathrm{O}_{3}$ particles $(\leq 0.1 \mathrm{~mm})$ are shown in Fig. 1, in which the results ${ }^{1)}$ for $\mathrm{C}_{3} \mathrm{~A}(\leq 0.1 \mathrm{~mm})$ are also included for comparison. It can be seen that the $\mathrm{F}$ immobilization by $\mathrm{C}_{2} \overline{\mathrm{F}}$ does not occur. However, $\mathrm{Ca}_{2}(\mathrm{Al}, \mathrm{Fe})_{2} \mathrm{O}_{5}$ demonstrates a good ability of removing $\mathrm{F}$ and the rate of $\mathrm{F}$ immobiliza- tion increases with an increase of $\mathrm{Al} / \mathrm{Fe}$ ratio in the $\mathrm{Ca}_{2}(\mathrm{Al}, \mathrm{Fe})_{2} \mathrm{O}_{5}$ solid solution. This can be explained by the fact that the hydration rate of ferrites increases with increasing $\mathrm{Al} / \mathrm{Fe}$ ratio. On the other hand, the $\mathrm{C}_{3} \mathrm{~A}-5 \% \mathrm{Fe}_{2} \mathrm{O}_{3}$ solid solution $\left(\mathrm{C}_{3} \mathrm{~A}-5 \% \mathrm{Fe}_{2} \mathrm{O}_{3}\right.$, thereafter $)$ demonstrates faster decrease of $\mathrm{F}$ content than the $\mathrm{Ca}_{2}(\mathrm{Al}, \mathrm{Fe})_{2} \mathrm{O}_{5}$ solid solution, especially at the beginning of the reaction. However, the F immobilization rate is obviously slower, compared to iron-free $\mathrm{C}_{3} \mathrm{~A}$.

The initial rates of releasing the $\mathrm{Ca}$ and $\mathrm{Al}$ contents in an aqueous solution suggest that the hydration ability of these minerals is in the increasing order of $\mathrm{C}_{2} \overline{\mathrm{F}} \ll \mathrm{Ca}_{2}(\mathrm{Al}, \mathrm{Fe})_{2} \mathrm{O}_{5}$ $<\mathrm{C}_{3} \mathrm{~A}-5 \% \mathrm{Fe}_{2} \mathrm{O}_{3}<\mathrm{C}_{3} \mathrm{~A}$, which is in good agreement with the rate of $\mathrm{F}$ immobilization. Both $\mathrm{Ca}_{2}(\mathrm{Al}, \mathrm{Fe})_{2} \mathrm{O}_{5}$ and $\mathrm{C}_{3} \mathrm{~A}-$ $5 \% \mathrm{Fe}_{2} \mathrm{O}_{3}$ reduce the $\mathrm{F}$ content in solution to the same level as that by $\mathrm{C}_{3} \mathrm{~A}$ after about $12 \mathrm{~h}$-shaking. This indicates that the major F-containing hydration product formed by them has a similar capability of holding $\mathrm{F}$ as that formed by $\mathrm{C}_{3} \mathrm{~A}$, which has been known as F-containing hydrogarnet phase $\left(\mathrm{Ca}_{3} \mathrm{Al}_{2}(\mathrm{OH}, \mathrm{F})_{12}\right) .{ }^{1)}$ It is also noted that the concentration of $\mathrm{Fe}^{3+}$ ion in an aqueous solution is extremely low comparing with those of $\mathrm{Ca}$ and $\mathrm{Al}$ ions.

$\mathrm{X}$-ray analysis revealed that no hydration products were identified for $\mathrm{C}_{2} \overline{\mathrm{F}}$ probably due to their small quantity. The main hydration product formed from $\mathrm{Ca}_{2} \mathrm{Al}_{1.36} \mathrm{Fe}_{0.64} \mathrm{O}_{5}$ and $\mathrm{C}_{4} \mathrm{~A} \overline{\mathrm{F}}$ has almost the same X-ray diffraction pattern to the hydrogarnet phase, $\mathrm{Ca}_{3} \mathrm{Al}_{2}(\mathrm{OH})_{12}$. It was confirmed by electron microprobe analysis that this hydrate appears to be an iron solid solution of $\mathrm{Ca}_{3} \mathrm{Al}_{2}(\mathrm{OH})_{12}$ phase containing $\mathrm{F}$, that is, $\mathrm{Ca}_{3}(\mathrm{Al}, \mathrm{Fe})_{2}(\mathrm{OH}, \mathrm{F})_{12}$. In addition, the $\mathrm{C}_{2} \mathrm{~A} \cdot 8 \mathrm{H}_{2} \mathrm{O}$ and $\mathrm{C}_{3} \mathrm{~A} \cdot \mathrm{Ca}(\mathrm{OH})_{2} \cdot 18 \mathrm{H}_{2} \mathrm{O}$ phases were also identified as a minor phase. The major hydration product for $\mathrm{C}_{3} \mathrm{~A}-$ $5 \% \mathrm{Fe}_{2} \mathrm{O}_{3}$ was also $\mathrm{Ca}_{3} \mathrm{Al}_{2}(\mathrm{OH})_{12}$ containing a small amount of iron (less than 1 mass\%), as confirmed by electron microprobe analysis. The finding that the rate of $\mathrm{F}$ immobilization by $\mathrm{C}_{3} \mathrm{~A}-5 \% \mathrm{Fe}_{2} \mathrm{O}_{3}$ is slower than that by $\mathrm{C}_{3} \mathrm{~A}$ may

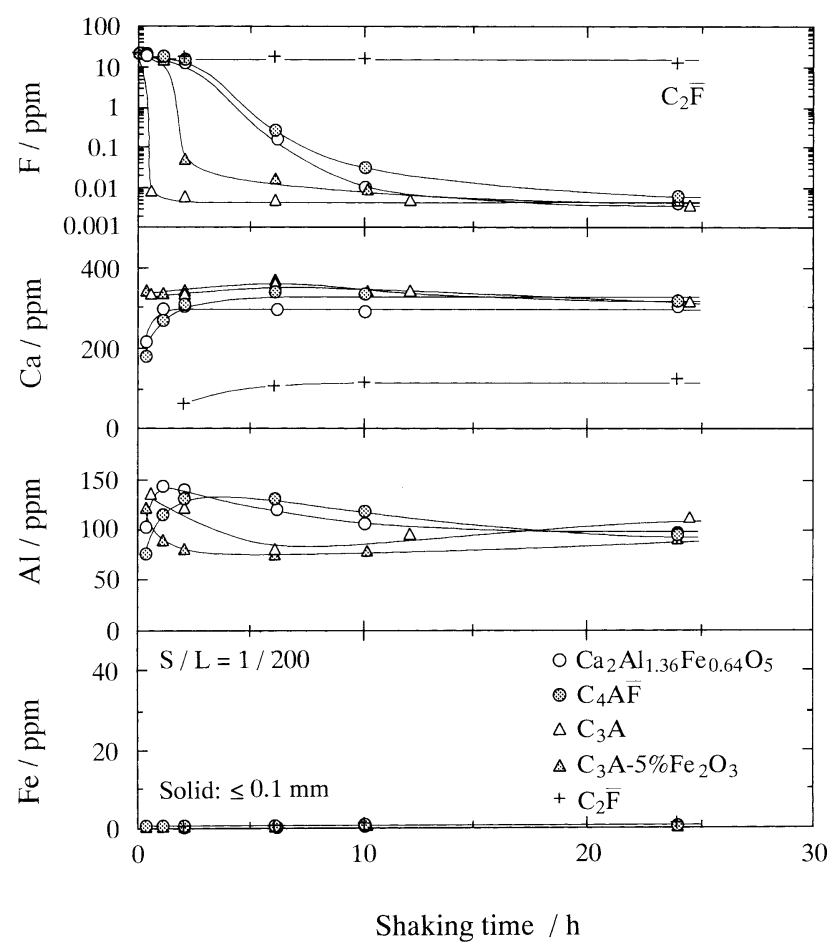

Fig. 1. Immobilization of $\mathrm{F}$ in aqueous solution by ferrites. 
$2 \mathrm{~h}$

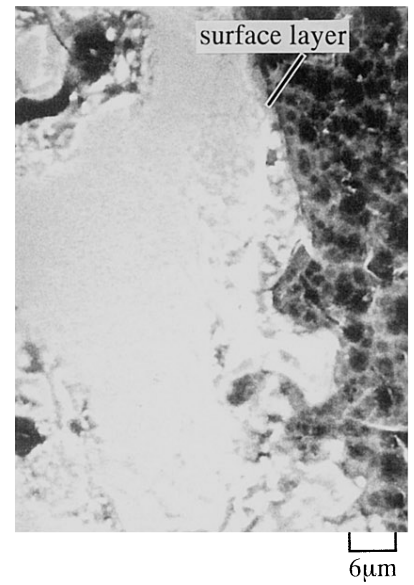

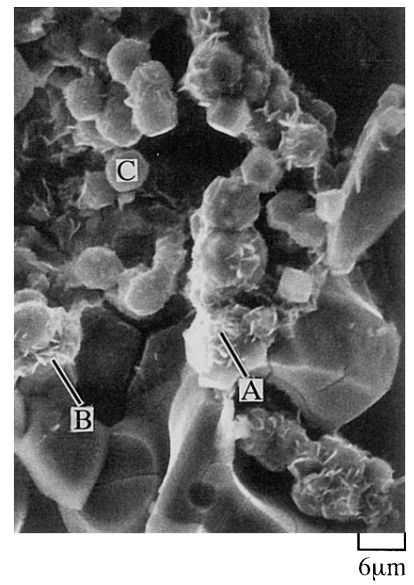

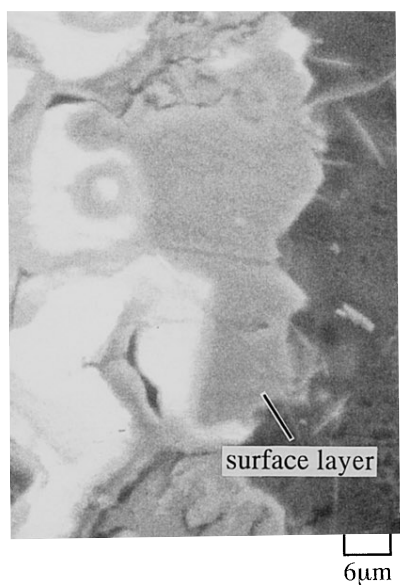

$24 \mathrm{~h}$

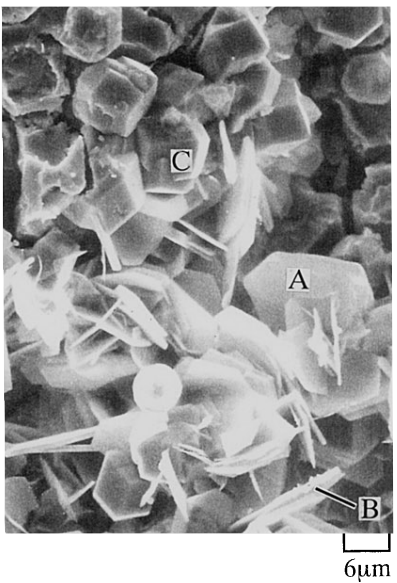

Fig. 2. Morphology of a hydrated $\mathrm{Ca}_{2} \mathrm{Al}_{1.36} \mathrm{Fe}_{0.64} \mathrm{O}_{5}$ particle under static condition; $\mathrm{A}$ : $\mathrm{C}_{2} \mathrm{~A} \cdot 8 \mathrm{H}_{2} \mathrm{O}$ (no $\mathrm{F}$ ), $\mathrm{B}$ : $\mathrm{C}_{3} \mathrm{~A} \cdot \mathrm{Ca}(\mathrm{OH})_{2} \cdot 18 \mathrm{H}_{2} \mathrm{O}(\% \mathrm{~F}=0-0.4)$, and $\mathrm{C}: \mathrm{Ca}_{3} \mathrm{Al}_{1.54} \mathrm{Fe}_{0.46}\left[(\mathrm{OH})_{1-x} \mathrm{~F}_{x}\right]_{12}(x=0-0.13)$.

$2 \mathrm{~h}$

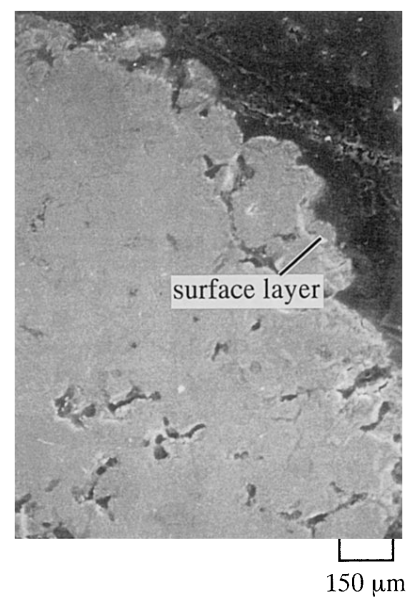

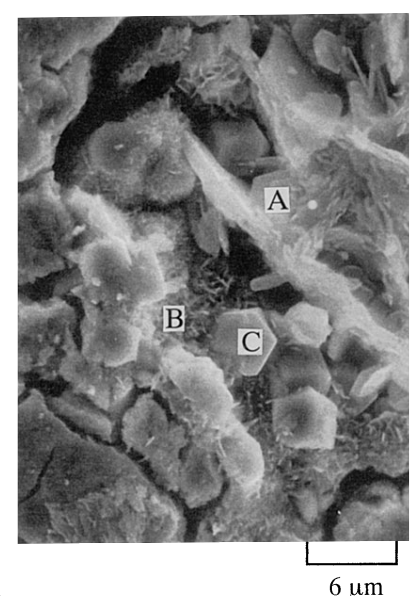

$24 \mathrm{~h}$

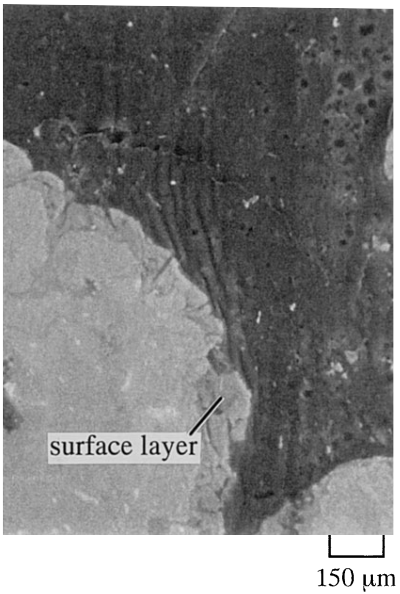

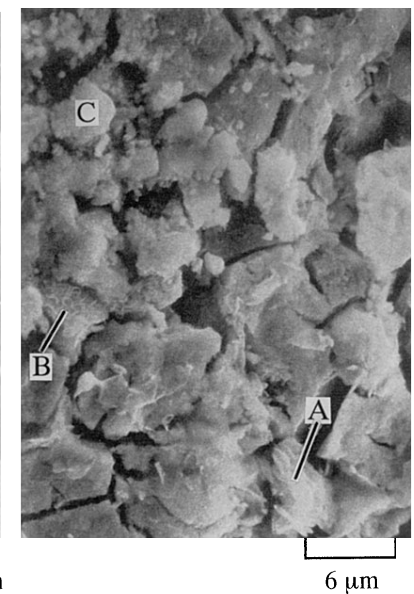

Fig. 3. Morphology of a hydrated $\mathrm{Ca}_{2} \mathrm{Al}_{1.36} \mathrm{Fe}_{0.64} \mathrm{O}_{5}$ particle under shaking condition; $\mathrm{A}$ : $\mathrm{C}_{2} \mathrm{~A} \cdot 8 \mathrm{H}_{2} \mathrm{O}$ (no $\mathrm{F}$ ), $\mathrm{B}$ : $\mathrm{C}_{3} \mathrm{~A} \cdot \mathrm{Ca}(\mathrm{OH})_{2} \cdot 18 \mathrm{H}_{2} \mathrm{O}(\% \mathrm{~F}=0-0.3)$, and $\mathrm{C}: \mathrm{Ca}_{3} \mathrm{Al}_{1.54} \mathrm{Fe}_{0.46}\left[(\mathrm{OH})_{1-x} \mathrm{~F}_{x}\right]_{12}(x=0-0.13)$.

be due to the fact that the retarding effect of a surface layer of reaction products may be greater when the surface layer contains ion, as observed by Boikova et. al. ${ }^{3)}$

The surface of a $\mathrm{C}_{2} \overline{\mathrm{F}}$ particle hydrated for $24 \mathrm{~h}$ in 20 mass ppm F-containing aqueous solution under shaking condition was examined by electron microprobe analysis. Hexagonal crystal $\mathrm{C}_{4} \overline{\mathrm{F}} \cdot 13 \mathrm{H}_{2} \mathrm{O}$ and amorphous $\mathrm{Fe}(\mathrm{OH})_{3}$ were identified and no significant amount of $\mathrm{F}$ was found in both phases.

The morphologies of a hydrated $\mathrm{Ca}_{2} \mathrm{Al}_{1.36} \mathrm{Fe}_{0.64} \mathrm{O}_{5}$ particle obtained at 2 and $24 \mathrm{~h}$ under static and shaking conditions are shown in Figs. $\mathbf{2}$ and 3, respectively. It can be seen from Fig. 2 that cubic crystals (C) along with two hexagonal crystals (A and B) are formed on the surface of a hydrated particle. Electron microprobe analysis revealed that the cubic hydrate corresponds to the iron- and F-containing hydrogarnet phase with the composition of $\mathrm{Ca}_{3} \mathrm{Al}_{1.54} \mathrm{Fe}_{0.46}$ $\left[(\mathrm{OH})_{1-x} \mathrm{~F}_{x}\right]_{12}(x=0-0.13)$. The hexagonal hydrates $\mathrm{A}$ and $\mathrm{B}$ correspond to the iron-containing $\mathrm{C}_{2} \mathrm{~A} \cdot 8 \mathrm{H}_{2} \mathrm{O}$ and $\mathrm{C}_{3} \mathrm{~A}$. $\mathrm{Ca}(\mathrm{OH})_{2} \cdot 18 \mathrm{H}_{2} \mathrm{O}$ phases, respectively. The former contained no $\mathrm{F}$, but the latter contained $\mathrm{F}$ up to 0.4 mass $\%$. The surface layer consisted of mainly iron-containing hydrogarnet phase and its thickness increased with holding time.
Under the shaking condition the amount of iron-containing hydrogarnet phase (C) increases compared with that under static condition, as shown in Fig. 3. The surface layer at $2 \mathrm{~h}$ is thinner and denser than that observed under static condition. The amount of iron-containing hexagonal crystals of $\mathrm{C}_{2} \mathrm{~A} \cdot 8 \mathrm{H}_{2} \mathrm{O}(\mathrm{A})$ and $\mathrm{C}_{3} \mathrm{~A} \cdot \mathrm{Ca}(\mathrm{OH})_{2} \cdot 18 \mathrm{H}_{2} \mathrm{O}(\mathrm{B})$ is less than that under static condition. This is due to the fact that these hexagonal crystals are metastable and change to iron-containing hydrogarnet phase, as observed by Collepardi el at. ${ }^{4}$ The formation of amorphous $\mathrm{Fe}(\mathrm{OH})_{3}$ which did not contribute to the $\mathrm{F}$ immobilization was also confirmed by electron microprobe analysis.

The $\mathrm{Ca}_{3}(\mathrm{Al}, \mathrm{Fe})_{2}(\mathrm{OH})_{12}$ phase forms a complete solid solution in the $\mathrm{Ca}_{3} \mathrm{Al}_{2}(\mathrm{OH})_{12}-\mathrm{Ca}_{3} \mathrm{Fe}_{2}(\mathrm{OH})_{12}$ solid solution series. It was found impossible to synthesize $\mathrm{Ca}_{3} \mathrm{Fe}_{2}(\mathrm{OH}, \mathrm{F})_{12}$ by either the direct hydration of anhydrous $\mathrm{C}_{2} \mathrm{~F}$ in the presence or absence of lime, or the reaction between ferric hydroxide gel and lime-containing aqueous solution. Even though the possibility that an unstable pure $\mathrm{Ca}_{3} \mathrm{Fe}_{2}(\mathrm{OH})_{12}$ phase may be formed exceptionally under special conditions still remains, it can be ruled out that this phase will play a significant role in the $\mathrm{F}$ immobilization. 


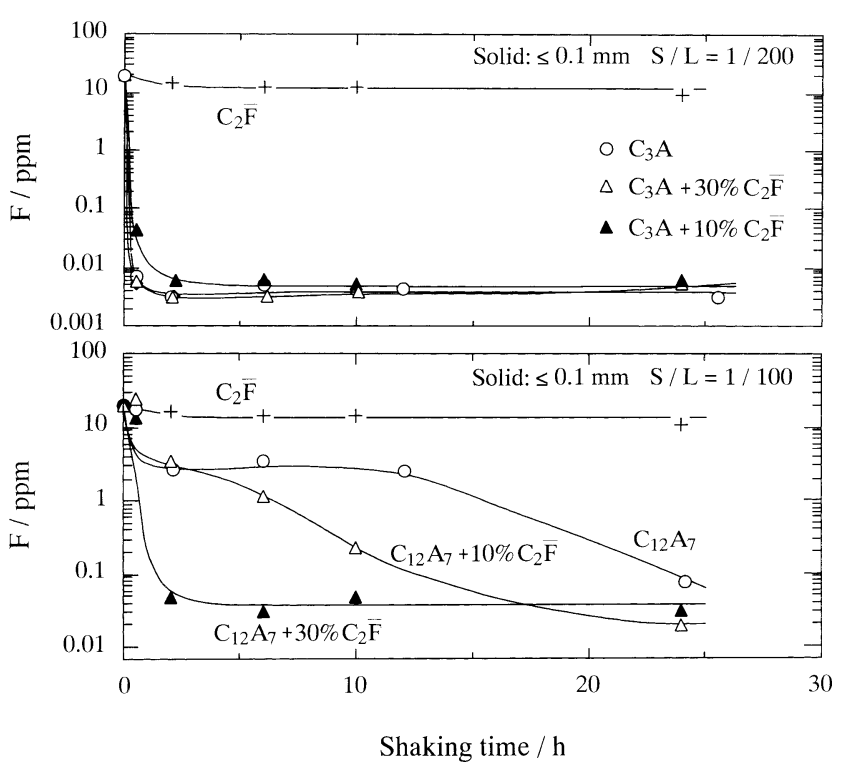

Fig. 4. Effect of $\mathrm{C}_{2} \overline{\mathrm{F}}$ on $\mathrm{F}$ immobilization by $\mathrm{C}_{3} \mathrm{~A}$ and $\mathrm{C}_{12} \mathrm{~A}_{7}$.

Table 1. Results of XRD analysis for the mixtures of $\mathrm{C}_{3} \mathrm{~A}+\mathrm{C}_{2} \overline{\mathrm{F}}$ and $\mathrm{C}_{12} \mathrm{~A}_{7}+\mathrm{C}_{2} \overline{\mathrm{F}}$.

\begin{tabular}{c|ccc|ccc}
\hline & $\mathrm{C}_{3} \mathrm{~A}$ & $\mathrm{C}_{3} \mathrm{~A}+$ & $\mathrm{C}_{3} \mathrm{~A}+$ & $\mathrm{C}_{12} \mathrm{~A}_{7}$ & $\mathrm{C}_{12} \mathrm{~A}_{7}+$ & $\mathrm{C}_{12} \mathrm{~A}_{7}+$ \\
& & $10 \% \mathrm{C}_{2} \overline{\mathrm{F}}$ & $30 \% \mathrm{C}_{2} \overline{\mathrm{F}}$ & & $10 \% \mathrm{C}_{2} \overline{\mathrm{F}}$ & $30 \% \mathrm{C}_{2} \overline{\mathrm{F}}$ \\
\hline $\mathrm{Ca}_{3} \mathrm{Al}_{2}(\mathrm{OH})_{12}$ & $\odot$ & $\odot$ & $\odot$ & $\times$ & $\times$ & $\square$ \\
$\mathrm{C}_{3} \mathrm{~A} \cdot \mathrm{Ca}(\mathrm{OH})_{2}$ & $\triangle$ & $\triangle$ & $\triangle$ & $\odot$ & $\odot$ & $\odot$ \\
$18 \mathrm{H}_{2} \mathrm{O}$ & $\triangle$ & $\triangle$ & $\triangle$ & $\triangle$ & $\triangle$ & $\bigcirc$ \\
$\mathrm{C}_{2} \mathrm{~A} \cdot 8 \mathrm{H}_{2} \mathrm{O}$ & $\triangle$ & $\triangle$ & $\square$ & $\square$ \\
$\begin{array}{c}\mathrm{C}_{3} \mathrm{~A} \cdot \times \mathrm{H}_{2} \mathrm{O} \\
(\mathrm{x}=8 \sim 10)\end{array}$ & $\square$ & $\square$ & $\square$ & $\square$ & $\square$ & $\square$ \\
\hline
\end{tabular}

Amount: $($ ) $>>>>\triangle, \quad \times$ : not detected.

\subsection{Effect of $\mathrm{C}_{2} \overline{\mathrm{F}}$ on $\mathrm{F}$ Immobilization by $\mathrm{C}_{3} \mathrm{~A}$ and $\mathrm{C}_{12} \mathrm{~A}_{7}$}

In the previous section, it was found that $\mathrm{C}_{2} \overline{\mathrm{F}}$ particles alone have little effect on $\mathrm{F}$ immobilization in comparison with ferrite, $\mathrm{Ca}_{2}(\mathrm{Al}, \mathrm{Fe})_{2} \mathrm{O}_{5}$ which strongly contributes to the $\mathrm{F}$ immobilization. In this section, $\mathrm{C}_{3} \mathrm{~A}$ or $\mathrm{C}_{12} \mathrm{~A}_{7}$ particles $(\leq 0.1 \mathrm{~mm})$ together with $\mathrm{C}_{2} \overline{\mathrm{F}}$ particles $(\leq 0.1 \mathrm{~mm})$ were added to a F-containing aqueous solution and the shaking test was carried out.

The effect of the $\mathrm{C}_{2} \overline{\mathrm{F}}$ addition on the $\mathrm{F}$ immobilization by $\mathrm{C}_{3} \mathrm{~A}$ and $\mathrm{C}_{12} \mathrm{~A}_{7}$ is shown in the upper and the lower diagram of Fig. 4, respectively. The results ${ }^{1)}$ for $\mathrm{C}_{3} \mathrm{~A}$ and $\mathrm{C}_{12} \mathrm{~A}_{7}(\leq 0.1 \mathrm{~mm})$ are also included for comparison. The $\mathrm{F}$ immobilization by $\mathrm{C}_{3} \mathrm{~A}$ is not affected to any important degree by the addition of $\mathrm{C}_{2} \overline{\mathrm{F}}$, as shown in the upper diagram of Fig. 4. However, the addition of $\mathrm{C}_{2} \overline{\mathrm{F}}$ to $\mathrm{C}_{12} \mathrm{~A}_{7}$ improves the $\mathrm{F}$ immobilization, as shown in the lower diagram of Fig. 4. Especially, the $F$ content decreases sharply in the case of $\mathrm{C}_{12} \mathrm{~A}_{7}+30 \% \mathrm{C}_{2} \overline{\mathrm{F}}$.

XRD analysis was made on filtered residue obtained after shaking for $2 \mathrm{~h}$. The results are summarized in Table 1 where the results ${ }^{1)}$ for $\mathrm{C}_{3} \mathrm{~A}$ and $\mathrm{C}_{12} \mathrm{~A}_{7}$ are also given. It can be seen that in the case of $\mathrm{C}_{3} \mathrm{~A}$ the hydration products are the same in the presence or the absence of $\mathrm{C}_{2} \overline{\mathrm{F}}$ and the main phase is $\mathrm{Ca}_{3} \mathrm{Al}_{2}(\mathrm{OH})_{12}$. In the case of $\mathrm{C}_{12} \mathrm{~A}_{7}$, however, with the addition of $30 \% \mathrm{C}_{2} \overline{\mathrm{F}}$ a small amount of $\mathrm{Ca}_{3} \mathrm{Al}_{2}(\mathrm{OH})_{12}$

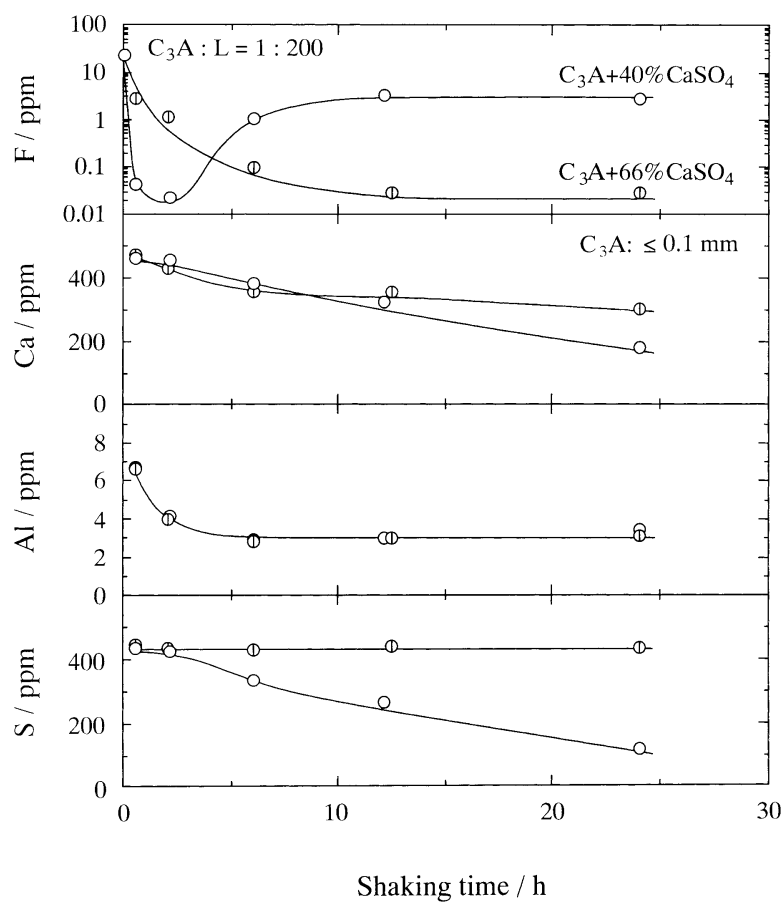

Fig. 5. Immobilization of $\mathrm{F}$ in aqueous solution by the formation of ettringite.

phase is identified, which is effective to the F immobilization. ${ }^{1)}$ These results of XRD analysis explains the phenomena observed in Fig. 4.

As confirmed by electron microprobe analysis, in the presence of $\mathrm{C}_{2} \overline{\mathrm{F}}$, the $\mathrm{Ca}_{3} \mathrm{Al}_{2}(\mathrm{OH})_{12}$ phase formed for $\mathrm{C}_{3} \mathrm{~A}$ and $\mathrm{C}_{12} \mathrm{~A}_{7}$ contained $\mathrm{F}$, as well as Fe. Therefore, it can be said that the addition of $\mathrm{C}_{2} \overline{\mathrm{F}}$ favors the formation of the $\mathrm{Ca}_{3}(\mathrm{Al}, \mathrm{Fe})_{2}(\mathrm{OH}, \mathrm{F})_{12}$ phase and accelerates the $\mathrm{F}$ immobilization process of $\mathrm{C}_{12} \mathrm{~A}_{7}$.

\subsection{Immobilization of $F$ by the Formation of Et- tringite}

\subsubsection{F Immobilization}

The mixture of $\mathrm{C}_{3} \mathrm{~A}$ and gypsum $\left(\mathrm{CaSO}_{4} \cdot 2 \mathrm{H}_{2} \mathrm{O}\right)$ was added to 20 mass ppm F-containing aqueous solution at $\mathrm{C}_{3} \mathrm{~A} /$ liquid ratio $=1 / 200$ in weight. The results of the shaking experiments for $\mathrm{C}_{3} \mathrm{~A}+40 \mathrm{mass} \% \mathrm{CaSO}_{4}$ and $\mathrm{C}_{3} \mathrm{~A}+$ $66 \mathrm{mass} \% \mathrm{CaSO}_{4}$ are shown in Fig. 5. It can be seen that the behavior of $\mathrm{F}$ content is influenced by the amount of $\mathrm{CaSO}_{4}$. In the case of $\mathrm{C}_{3} \mathrm{~A}+40$ mass $\% \mathrm{CaSO}_{4}$ the $\mathrm{F}$ content decreases rapidly at the beginning, reaches the minimum at about $2 \mathrm{~h}$, and then increases up to around 3 mass ppm. However, in the case of $\mathrm{C}_{3} \mathrm{~A}+66 \mathrm{mass} \% \mathrm{CaSO}_{4}$ the $\mathrm{F}$ content decreases steadily and reaches a constant value approximately at $0.03 \mathrm{ppm}$ after $12 \mathrm{~h}$. Correspondingly, it is observed that the $\mathrm{S}$ content is nearly the same level for both cases in the beginning of $2 \mathrm{~h}$, indicating that the solution is saturated with $\mathrm{S}$ by the addition of $\mathrm{CaSO}_{4}$ over 40 mass $\%$. Thereafter, the $\mathrm{S}$ content decreases in the case of $\mathrm{C}_{3} \mathrm{~A}+$ 40 mass $\% \mathrm{CaSO}_{4}$, while it remains nearly constant for $\mathrm{C}_{3} \mathrm{~A}+$ $66 \mathrm{mass} \% \mathrm{CaSO}_{4}$. It is also noted that the $\mathrm{Al}$ content is extremely low in both cases.

X-ray patterns of hydrated mixtures of $\mathrm{C}_{3} \mathrm{~A}$ and $\mathrm{CaSO}_{4}$ obtained after 2 and $24 \mathrm{~h}$ are shown in Fig. 6. It is clear that in the case of $\mathrm{C}_{3} \mathrm{~A}+40 \mathrm{mass} \% \mathrm{CaSO}_{4}$ the hydration products 


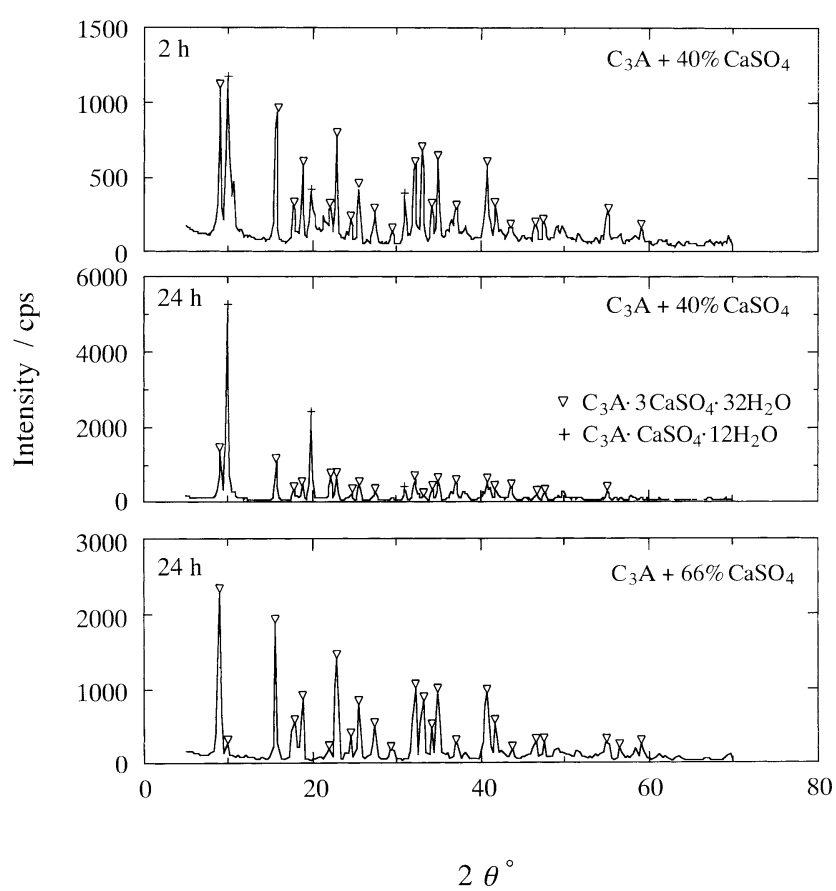

Fig. 6. X-ray patterns of hydrated mixtures of $\mathrm{C}_{3} \mathrm{~A}$ and $\mathrm{CaSO}_{4}$.

are ettringite $\left(\mathrm{C}_{3} \mathrm{~A} \cdot 3 \mathrm{CaSO}_{4} \cdot 32 \mathrm{H}_{2} \mathrm{O}\right)$ and monosulfate $\left(\mathrm{C}_{3} \mathrm{~A} \cdot \mathrm{CaSO}_{4} \cdot 12 \mathrm{H}_{2} \mathrm{O}\right)$. At $2 \mathrm{~h}$ the amount of the former appears to be larger than that of the latter, as shown in the upper diagram. At $24 \mathrm{~h}$ the latter becomes the main one, as shown in the middle diagram. These results suggest that ettringite is formed at first and then converts to monosulfate. As will be pointed out later, ettringite phase is the one responsible for the $\mathrm{F}$ immobilization. The drastic decrease of the $\mathrm{F}$ concentration at initial stage shown in Fig. 5 for $\mathrm{C}_{3} \mathrm{~A}+40 \mathrm{mass} \% \mathrm{CaSO}_{4}$ can be explained by the formation of ettringite and the increase of $\mathrm{F}$ content after $2 \mathrm{~h}$ is attributed to the decomposition of ettringite. It is further noted from Fig. 5 that this decomposition is caused by the decrease of $\mathrm{S}$ content in an aqueous solution.

In the case of $\mathrm{C}_{3} \mathrm{~A}+66 \mathrm{mass} \% \mathrm{CaSO}_{4}$, ettringite is the only hydration product through the experimental period of time, as shown in the lower diagram in Fig. 6. This can explain the F immobilization behavior shown in Fig. 5. It is considered that since the formation of ettringite layer on a $\mathrm{C}_{3} \mathrm{~A}$ particle might be much faster in the presence of a large amount of $\mathrm{CaSO}_{4}$, the process of $\mathrm{F}$ immobilization is retarded by this ettringite layer at beginning. It should be pointed out that the amount of $\mathrm{CaSO}_{4}$ in this mixture corresponds to the stochiometric amount needed for the formation of ettringite.

Morphology of the surface of $\mathrm{C}_{3} \mathrm{~A}$ particles hydrated for $24 \mathrm{~h}$ in 20 mass ppm F-containing aqueous solution in which 40 and 66 mass $\% \mathrm{CaSO}_{4}$ was added, respectively, is shown in Fig. 7. The only hydration product observed in the case of $\mathrm{C}_{3} \mathrm{~A}+66 \mathrm{mass} \% \mathrm{CaSO}_{4}$ is needle-like ettringite (A) which contains up to 2 mass percent $\mathrm{F}$. On the other hand, for $\mathrm{C}_{3} \mathrm{~A}+40$ mass $\% \mathrm{CaSO}_{4}$, monosulfate (B) was identified together with ettringite (A). The former appears to be smaller acicular crystal, while the latter is much larger comparing with that formed for $\mathrm{C}_{3} \mathrm{~A}+66 \mathrm{mass} \% \mathrm{CaSO}_{4}$. This finding suggests that the ettringite is formed in the early stage of the reaction and is decomposed to monosul-

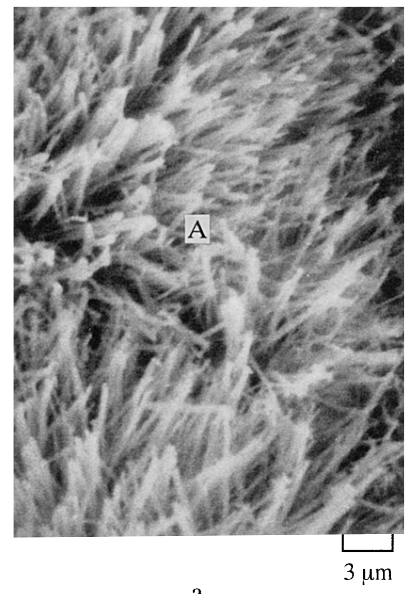

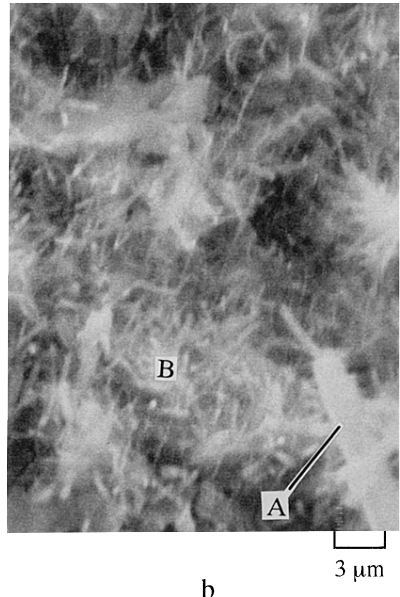

Fig. 7. SEM image of the surface of a $\mathrm{C}_{3} \mathrm{~A}$ particle hydrated in $20 \mathrm{ppm}$ F-containing aqueous solution in which $\mathrm{CaSO}_{4}$ was dissolved; (a) $\mathrm{C}_{3} \mathrm{~A}+66 \% \mathrm{CaSO}_{4} ;$ (b) $\mathrm{C}_{3} \mathrm{~A}+$ $40 \% \mathrm{CaSO}_{4} ; \quad \mathrm{A}: \mathrm{C}_{3} \mathrm{~A} \cdot 3 \mathrm{CaSO}_{4} \cdot 32 \mathrm{H}_{2} \mathrm{O}(\% \mathrm{~F}+0-2) ; \mathrm{B}$ : $\mathrm{C}_{3} \mathrm{~A} \cdot \mathrm{CaSO}_{4} \cdot 12 \mathrm{H}_{2} \mathrm{O}$.

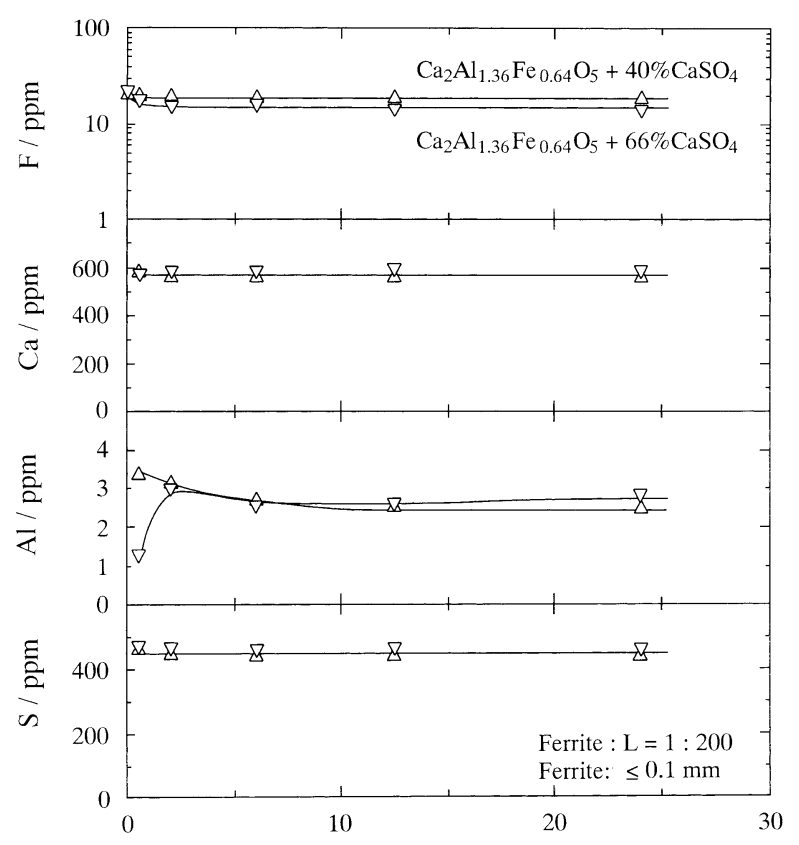

Shaking time / $\mathrm{h}$

Fig. 8. Immobilization of $\mathrm{F}$ in aqueous solution by the mixture of $\mathrm{Ca}_{2} \mathrm{Al}_{1.36} \mathrm{~F}_{\mathrm{e} 0.64} \mathrm{O}_{5}$ and $\mathrm{CaSO}_{4}$.

fate in the case of $\mathrm{C}_{3} \mathrm{~A}+40 \mathrm{mass} \% \mathrm{CaSO}_{4}$. No significant amount of $\mathrm{F}$ was identified in monosulfate phase. It can be seen that the microscopic observation corresponds well to the results of XRD analysis, as well as the results for the F immobilization behavior shown in Fig. 5 .

The results for $\mathrm{F}$ immobilization by the mixture of ferrite $\left(\mathrm{Ca}_{2} \mathrm{Al}_{1.36} \mathrm{Fe}_{0.64} \mathrm{O}_{5}\right)$ and $\mathrm{CaSO}_{4}$ are shown in Fig. 8. The amount of $\mathrm{CaSO}_{4}$ added in 20 mass ppm F-containing solution is the same as that shown in Fig. 5. It can be seen that the $\mathrm{F}$ immobilization does not occur within the experimental period of time and both $\mathrm{Ca}$ and $\mathrm{S}$ contents remain constant. As revealed by XRD, no hydration products were identified. This suggests that the hydration of $\mathrm{Ca}_{2} \mathrm{Al}_{1.36} \mathrm{Fe}_{0.64} \mathrm{O}_{5}$ is retarded by the presence of $\mathrm{CaSO}_{4}$.

In order to prepare an iron-based ettringite, $\mathrm{C}_{3} \overline{\mathrm{F}}$. 

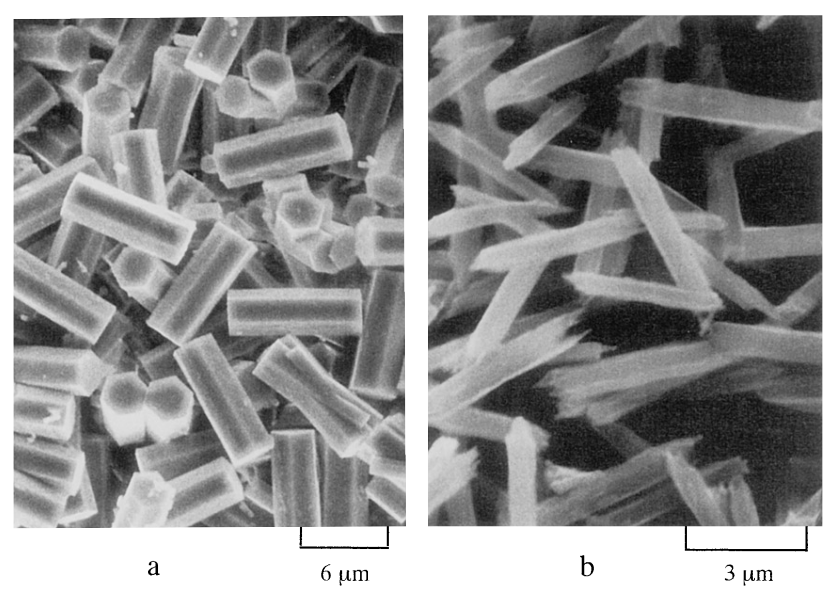

Fig. 9. Morphologies of fluorine-substituted ettringite phases; shaking time $=6$ days, $F$ (init.) $=1240 \mathrm{ppm}$. (a) $\mathrm{C}_{3} \overline{\mathrm{F}}$. $3 \mathrm{CaSO}_{4} \cdot 32 \mathrm{H}_{2} \mathrm{O}$, (b) $\mathrm{C}_{3} \mathrm{~A} \cdot 3 \mathrm{CaSO}_{4} \cdot 32 \mathrm{H}_{2} \mathrm{O}$

$3 \mathrm{CaSO}_{4} \cdot 32 \mathrm{H}_{2} \mathrm{O}$, a mixture of $\mathrm{CaO}$ and $\mathrm{Fe}_{2} \mathrm{SO}_{4}$ in stochiometric ratio for the formation of ettringte, was added into the aqueous solution containing 1240 mass ppm F, followed by $30 \mathrm{~h}$ shaking. The SEM image of hydration product is shown in Fig. 9(a). Al-based ettringite was also synthesized in a similar manner by using $\mathrm{CaO}$ and $\mathrm{Al}_{2} \mathrm{SO}_{4}$, and its morphology is shown in Fig. 9(b). It is clear that the morphologies of these two ettringite phases are different. The Albased ettringite appears to be acicular crystals which are about $5 \mu \mathrm{m}$ long, while the Fe-based ettringite is prismatic crystals which are much longer, about $9 \mu \mathrm{m}$. In the case of Fe-based ettringite, it was found that the value of $F$ content determined by electron microprobe analysis depends on crystal plane. If the X-ray beam was focused on the plane perpendicaular to the prism axis, the $\mathrm{F}$ content was about 2 mass $\%$. However, the F content was 1 mass $\%$ on the plane parallel to the prism axis. In the case of Al-based ettringite, only the $\mathrm{F}$ content on the plane parallel to the prism axis was evaluated and the F uptake was about 1 mass $\%$.

\subsubsection{Immobilization Mechanism}

It is known that the structure of ettringite is based on two distinct structural components ${ }^{5)}$; columns of $\left\{\mathrm{Ca}_{6}\left[(\mathrm{Al}, \mathrm{Fe})(\mathrm{OH})_{6}\right]_{2} \cdot 24 \mathrm{H}_{2} \mathrm{O}\right\}^{6+}$ and channels of $\left\{\left(\mathrm{SO}_{4}\right)_{3}\right.$. $\left.2 \mathrm{H}_{2} \mathrm{O}\right\}^{6-}$ which contain four sites, of which three are occupied by sulfate and one by two water molecules. With this structure a modest deviation in composition can be tolerated without causing a change in structure. The ions available for substitution in the ettringite structure are $\mathrm{Ca}^{2+}, \mathrm{Al}^{3+}$, $\mathrm{SO}_{4}^{2-}$ and $\mathrm{OH}^{-}$and among them only $\mathrm{OH}^{-}$and $\mathrm{SO}_{4}^{2-}$ are replaceable by $\mathrm{F}^{-}$. Comparing with $\mathrm{OH}^{-}$ion site in columns, $\mathrm{SO}_{4}^{2-}$ site in channels is much more favorable for the ion substitution. A variety of this sulfate-substitution occurrences have been reported, like $\mathrm{Cl}^{-6}$ and $\mathrm{OH}^{-7)}$ ions. Considering the similarities of $\mathrm{F}^{-}$with $\mathrm{Cl}^{-}, \mathrm{OH}^{-}$, it seems reasonable to assume that the $\mathrm{F}$ immobilization occurs through the substitution of $\mathrm{F}^{-}$ion for this $\mathrm{SO}_{4}^{2-}$ site.

This assumption is supported by the relation of the value of $\mathrm{F}$ content to the crystal plane, as mentioned above. The number of channels in the direction parallel to the prism axis in the unit cell of ettringite is twice as many as that in the direction perpendicular to the prism axis because a half of channels is shielded by columns. Therefore, if the $\mathrm{F}$ immobilization occurs through the substitution of $\mathrm{F}^{-}$for $\mathrm{SO}_{4}^{2-}$ sites in channels, the value of $\mathrm{F}$ uptake obtained by electron microprobe analysis will depend on the crystal plane on which the X-ray beam is introduced.

The F immobilization mechanism can be represented by the following reaction:

$$
\begin{aligned}
\mathrm{C}_{3} \mathrm{~A}+3 \mathrm{CaSO}_{4}+6 x \mathrm{~F}^{-}+32 \mathrm{H}_{2} \mathrm{O} \rightleftharpoons \\
\mathrm{C}_{3} \mathrm{~A} \cdot 3 \mathrm{Ca}\left[\left(\mathrm{SO}_{4}\right)_{1-x} \mathrm{~F}_{2 x}\right] \cdot 32 \mathrm{H}_{2} \mathrm{O}+3 x \mathrm{SO}_{4}^{2-}
\end{aligned}
$$

To balance charges, one $\mathrm{SO}_{4}^{2-}$ site is replaced by $2 \mathrm{~F}^{-}$ions, and on the basis of the aforementioned results obtained by electron microprobe analysis, the substitution degree of $x$ is up to 0.2 . Therefore, 0.2 mole of ion per ettringite molecular can be replaced by 0.4 mole of $\mathrm{F}^{-}$ion at maximum.

Based on the present study, it is said that fluorine in waste water can be immobilized by using stabilizing agents. For this purpose, the stability of F-containing hydrates should be examined at various $\mathrm{pH}$ values.

\section{Summary}

The F immobilization by the formation of iron-containing hydrogarnet phase and ettringite phase has been studied. The effect of $\mathrm{C}_{2} \overline{\mathrm{F}}$ on the $\mathrm{F}$ immobilization by $\mathrm{C}_{3} \mathrm{~A}$ and $\mathrm{C}_{12} \mathrm{~A}_{7}$ is also discussed. Based on these results, the following conclusions are summarized:

(1) The $\mathrm{F}$ immobilization by $\mathrm{Ca}_{2}(\mathrm{Al}, \mathrm{Fe})_{2} \mathrm{O}_{5}$ occurs through the formation of $\mathrm{Ca}_{3}(\mathrm{Al}, \mathrm{Fe})_{2}(\mathrm{OH}, \mathrm{F})_{12}$ and demonstrates a similar ability to the $\mathrm{F}$ immobilization by $3 \mathrm{CaO}$. $\mathrm{Al}_{2} \mathrm{O}_{3}$.

(2) $\mathrm{C}_{2} \overline{\mathrm{F}}$ does not immobilize $\mathrm{F}$, but the addition of $\mathrm{C}_{2} \overline{\mathrm{F}}$ to $\mathrm{C}_{12} \mathrm{~A}_{7}$ gives a positive effect on the $\mathrm{F}$ immobilization by $\mathrm{C}_{12} \mathrm{~A}_{7}$, which is due to the formation of $\mathrm{Ca}_{3}(\mathrm{Al}, \mathrm{Fe})_{2}(\mathrm{OH}, \mathrm{F})_{12}$.

(3) Ettringite can immobilize $\mathrm{F}$ through the substitution of $\mathrm{F}^{-}$for $\mathrm{SO}_{4}^{2-}$ site in channels.

\section{REFERENCES}

1) H. He and H. Suito: ISIJ Int., 41 (2001), 506.

2) H. He and H. Suito: ISIJ Int., 41 (2001), 513.

3) A. I. Boikova, L. V. Grishchenko and A. I. Domansky: 7th Int. Cong. on the Chemistry of Cement (7th ICCC), Vol. 4, Editions Septima, Paris, (1980), 460.

4) M. Collepardi, S. Monosi, G. Moriconi and M. Corradi: Cem. Concr. Res., 9 (1979), 431.

5) A. Moore and H. F. W. Taylor: Nature, 218 (1968), 1048.

6) H. E. Schwiete and U. Ludwig: Proc. of the 5th Int. Symp. on the Chemistry of Cement, The Cement Association of Japan, Tokyo, (1968), 37.

7) H. G. Midgley and D. Rosaman: Proc. of the 4th Int. Symp. on Chemistry of Cement, Vol. I, US Department of Commerce, Washington, (1960), 259. 